\title{
Special Report on the \\ Audit of the Management of Department of Energy Construction Projects
}

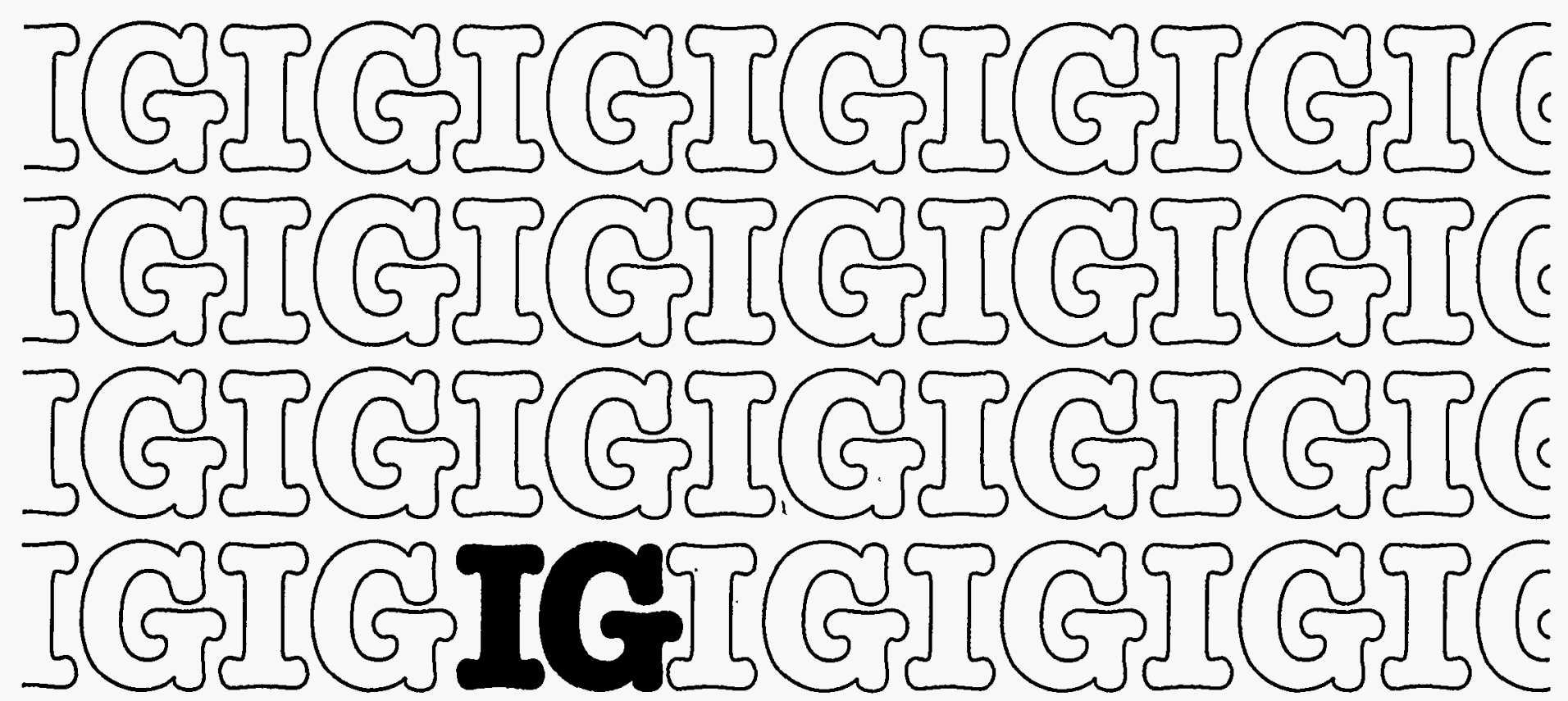


The Office of Inspector General wants to make the distribution of its reports as customer friendly and cost effective as possible. Therefore, this report will be available electronically through the Internet five to seven days after publication at the following alternative addresses:

\author{
Department of Energy Headquarters Gopher \\ gopher.hr.doe.gov \\ Department of Energy Headquarters Anonymous FTP \\ vm1.hqadmin.doe.gov \\ U.S. Department of Energy Human Resources and Administration \\ Home Page \\ http://www.hr.doe.gov/ig
}

Your comments would be appreciated and can be provided on the Customer Response Form attached to the report.

This report can be obtained from the

U.S. Department of Energy

Office of Scientific and Technical Information

P.O. Box 62

Oak Ridge, Tennessee 37831 


\section{memorandum}

DATE: November 21, 1996

REPLY TO

ATTN OF: IG-1

SUBJECT: INFORMATION: "Special Report on the Audit of the Management of Department of Energy Construction Projects"

To: The Secretary

\section{BACKGROUND:}

The Department's Fiscal Year 1996 budget submission of about $\$ 18$ billion included approximately $\$ 1.1$ billion for construction projects. Ensuring that these construction projects meet bonafide existing or future Departmental needs becomes increasingly important as the Department's mission evolves and as it faces additional budget reductions. To illustrate, as recently as November 12, 1996, the Department issued the final Programmatic Environmental Impact Statement for the Stockpile Stewardship and Management Program. This statement, in which the Department examined the future of three weapons laboratories, four industrial plants and the Nevada test site, included recommendations regarding the sizing of these facilities. Specifically, the statement treated the significant downsizing of components of the Y-12 Plant, Pantex, and the Kansas City Plant as preferred options.

In 1994 and 1995, the Office of Inspector General issued several reports on the Department's construction activities. In these reports, we expressed concern about the construction planning process and questioned whether planned construction was necessary to meet mission needs. The reports also pointed out that the Department did not ensure that originally identified needs were still valid several years after a project's conception. While Department management indicated that it had addressed problems identified at specific locations, the magnitude of the Department's construction program indicated that continued emphasis in this area is warranted.

The purpose of this report is to highlight issues dealing with opportunities to improve the planning process to avoid construction of unneeded or oversized facilities. By synthesizing the issues from prior reports, we hope to assist management in focusing its process improvement efforts to ensure that construction plans reflect emerging program and mission. changes and budget realities. 


\section{DISCUSSION:}

A specific objective of the Department's construction planning process is to ensure that current and future construction projects are needed to support the mission of the organization and are cost effective. Past Inspector General reports showed that (1) construction plans were not always updated when mission needs changed, and (2) projects were not needed or all alternatives were not fully evaluated prior to proceeding with construction of new facilities.

In our effort to understand the general environment preceding the actual start of new construction, we found that the extended elapsed time between identification of need and actual construction often encompassed significant program and/or mission changes. This necessitates that field project managers document mission needs and that they, along with Headquarters program managers, use this information to avoid expenditures for unneeded facilities. Our review of the Fiscal Year 1996 budget validation process showed that the field project manager was not required to indicate the extent to which the mission need was reassessed. Without documentation to clearly show that a continued need will exist for ongoing or planned construction projects, higher level management cannot evaluate this assertion of need.

To their credit, the Office of the Associate Deputy Secretary for Field Management and the respective Headquarters program and field offices had recognized that opportunities existed to improve the construction planning process. The management process for construction was being streamlined under Department Order 430.1, Life Cycle Asset Management, which will become effective when site specific performance measures are established as part of the respective management and operating or other prime operating contracts. Management also advised us of other improvements that have been recently implemented or planned such as the FY 1998 Project Review/Validation Guidance and the Joint Program Office Direction on Project Management.

We recommended that the Department emphasize the need for effective evaluations by field project managers of the Department's current and future mission needs as part of the annual approval process for ongoing and planned construction projects.

The Office of the Associate Deputy Secretary for Field Management agreed with the recommendation but expressed concern that the specific examples used in our analysis were no longer relevant. The Office of Energy Research disagreed with the recommendation stating that it puts the demonstration of mission need in the wrong place. Energy Research stated that the program manager, not the field project manager, is in the best position to determine and document mission need. We believe that the Energy Research position does not address subsequent changes which may effect the need for a project.

We were also provided data on recent actions and initiatives to improve the Department's approval process for construction projects. We recognize that management has initiated a number of process improvements that are designed to enhance the construction planning process and that it has canceled and downsized many construction projects. 
However, many of the Department's initiatives have not been fully implemented or tested and their effectiveness cannot be evaluated at the present time. Because of the magnitude of the Department's construction program, we believe that the Department's managers, both in the field and at Headquarters, need to maintain a vigilant attitude.

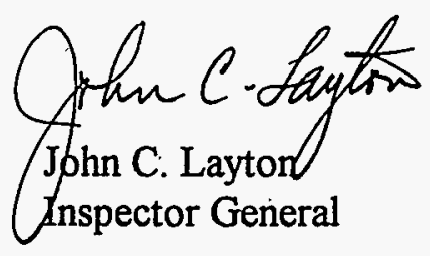

Attachment

cc: Deputy Secretary

Under Secretary

Assistant Secretary for Environmental Management

Assistant Secretary for Defense Programs

Director, Office of Energy Research

Associate Deputy Secretary for Field Management

Director, Office of Project and Fixed Asset Management 


\section{DISCLAIMER}

This report was prepared as an account of work sponsored by an agency of the United States Government. Neither the United States Government nor any agency thereof, nor any of their employees, makes any warranty, express or implied, of assumes any legal liability or responsibility for the accuracy, completeness, or usefulness of any information, apparatus, product, or process disclosed, or represents that its use would not infringe privately owned rights. Reference herein to any specific commercial product, process, or service by trade name, trademark, manufacturer, or otherwise does not necessarily constitute or imply its endorsement, recommendation, or favoring by the United States Government or any agency thereof. The views and opinions of authors expressed herein do not necessarily state or reflect those of the United States Government or any agency thereof. 
DISCLAIMER

Portions of this document may be illegible in electronic image products. Images are produced from the best available original document. 
U.S. DEPARTMENT OF ENERGY

OFFICE OF INSPECTOR GENERAL

\section{SPECIAL REPORT ON THE AUDIT OF THE MANAGEMENT OF DEPARTMENT OF ENERGY CONSTRUCTION PROJECTS}




\section{SPECIAL REPORT ON THE AUDIT OF THE MANAGEMENT OF}

DEPARTMENT OF ENERGY CONSTRUCTION PROJECTS

\section{TABLE OF CONTENTS}

Page

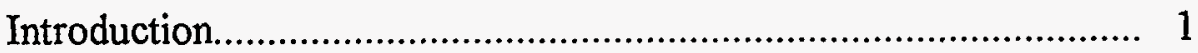

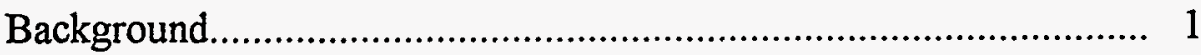

Construction Planning Process...................................................... 2

Factors Affecting Construction Planning Process................................ 4

Improvements Initiated by Management............................................. 5

Recommendation..................................................................... 7

Management Reaction................................................................ 7

Attachment A - Summary of Individual Audit Reports....................... 11

Attachment B - Scope and Methodology............................................. 14 


\section{U.S. DEPARTMENT OF ENERGY \\ OFFICE OF INSPECTOR GENERAL \\ OFFICE OF AUDIT SERVICES}

\section{SPECIAL REPORT ON THE AUDIT OF THE MANAGEMENT OF DEPARTMENT OF ENERGY CONSTRUCTION PROJECTS}

Audit Report Number: DOE/IG-0398

\section{INTRODUCTION}

The Department of Energy's Fiscal Year 1996 budget submission of about $\$ 18$ billion included approximately $\$ 1.1$ billion for construction projects. Ensuring that these construction projects meet bonafide existing or future Departmental needs becomes increasingly important as the Department's missions evolve. Several of the Department's original core missions, including the development and testing of nuclear weapons, are being replaced by environmental cleanup and commercial applications of science. At the same time, the Department's organizational structure and processes are changing as management moves to downsize and implement reinvention initiatives.

In 1994 and 1995, the Office of Inspector General issued several reports on the Department's construction activities. The reports expressed concerns about the construction planning process and questioned whether planned construction was necessary to meet mission needs. The reports also pointed out that the Department did not ensure that originally identified needs were still valid several years after a project's conception. Although the problems identified were at single locations, the magnitude of the construction program and the length of the planning process created a potential for the recurrence of similar problems. These audit reports are summarized in Attachment A to this report.

While Departmental management did not agree with all aspects of the audit reports, it canceled or downsized several of the construction projects. Also, we recognize that management has initiated a number of process improvements that are designed to enhance the construction planning process. The purpose of this report is to synthesize issues from these prior reports to assist management in focusing process improvement efforts to avoid construction of unneeded or oversized facilities.

\section{BACKGROUND}

The Department and the Comptroller General define mission as the responsibilities assigned by law to a specific agency to meet national needs. Missions are expressed in terms of specific purposes to be served which, by law, are the responsibility of that agency. A project is considered to meet a mission need if the facility to be constructed is necessary to accomplish the Department's program responsibilities. 
The Department is going through a period of rapid transformation with changes in requirements for facilities to support program responsibilities. Priorities have changed from weapons production to reducing weapons stockpiles, dismantling weapons, ensuring the continued viability of the enduring stockpile (i.e. stockpile stewardship and management), and disposing of waste. These new priorities come at a time of increasing attention to cutting the cost and size of Government. Ensuring that ongoing or planned construction projects will meet mission needs becomes more important because of these changes.

Headquarters program elements are responsible for overall program policy and planning, budget preparation, and broad program direction including oversight of project planning and management, which includes the engineering and construction process. Field organizations are responsible for implementing these program activities and supporting the Headquarters programming and budgeting process. The field project manager has primary responsibility for execution of projects from conceptual design through construction completion. The Office of the Associate Deputy Secretary for Field Management coordinates among the program offices and field elements to support the Department's project planning, management process, and the construction process.

A specific objective of the planning process is to ensure that construction projects are needed to support the mission of the organization and are cost effective. In initially establishing the mission need and developing the conceptual design for the project, the planning process requires program managers to identify and evaluate alternatives to satisfy the identified need. As part of the approval process, Departmental Orders 4700.1 and 430.1 both require the program manager and the project manager to (1) verify that planned construction is necessary to meet a valid mission need; (2) independently identify and consistently evaluate all competing project alternatives; and (3) reassess the need for planned construction projects when significant events occur such as a mission change, program redirection, or program downsizing.

In addition, the annual budget process requires a review of each project, including projects already under construction, for which funding is requested. Project data sheets prepared by Headquarters in coordination with field offices during the budget process are used to justify the need for proposed or ongoing projects. These sheets must be accurate and up-to-date and reflect mission changes because they are used during Department, Office of Management and Budget, and congressional budget reviews. Informed decisions on mission needs cannot be made without current, complete, and accurate data.

\section{CONSTRUCTION PLANNING PROCESS}

The Department's construction plans were not always updated to reflect emerging program and mission changes resulting in the potential construction of unneeded or oversized facilities. Office of Inspector General reports issued in 1994 and 1995 identified recurring problems when changes in mission needs were not fully considered in initially 
approving funding of new or continuing funding of ongoing construction projects. In addition, these reports identified instances where viable alternatives to the construction of new facilities were not fully considered. The reports, which identified opportunities for the Department to reduce spending on unneeded or oversized facilities, are summarized in Attachment $\mathrm{A}$ to this report.

\section{Changing Mission Needs}

Analysis of these reports showed that construction plans were not always reassessed when mission needs changed. Examples follow:

- In February 1994, our report on the "Audit of the Y-12 Construction Program" showed that the contractor's long-term construction plan was based on assumptions that may not be compatible with the known future mission of the facility. Subsequent to the audit, management reassessed ongoing construction giving consideration to the Y-12 Plant's changing mission and deleted \$53 million of ongoing construction projects.

- In May 1994, our report on the "Audit of the Uranium Solidification Facility at the Savannah River Site" showed that the Department continued to construct the facility even though its need to process liquid uranyl nitrate had significantly diminished when the reactor generating this liquid was placed in cold standby. The Department saved about $\$ 71$ million by suspending construction of the facility.

- In October 1995, our report on the "Audit of Construction of an Environmental, Safety, and Health Analytical Laboratory at the Pantex Plant" showed that the Department planned to construct the laboratory even though its mission requirements were being satisfied either at onsite or commercial laboratories. Construction had been approved because the Department relied on justifications that were not updated and were, therefore, inadequate. We recommended, and management agreed, that additional funding be suspended until the need was clearly established and a cost-benefit analysis performed. Management later canceled this construction project and saved about $\$ 8$ million.

\section{Viable Alternatives}

There were also several cases where projects were not needed or alternatives to construction were not fully evaluated prior to proceeding with construction of new facilities. Examples follow:

- In April 1995, our report on the "Audit of the Department of Energy's Environmental Molecular Sciences Laboratory" showed that the Office of Energy Research had not evaluated all practical alternatives before initiating construction of the proposed facility that was expected to cost about $\$ 230$ million when fully 
equipped. We recommended that the Department reevaluate the project to determine if there were less costly but equally effective alternatives that would meet mission needs. Management did not concur with our recommendation.

- In October 1995, our report on the "Audit of Construction Management at the Idaho National Engineering Laboratory" identified five construction projects totaling over $\$ 4$ million that were not needed and two others totaling $\$ 38$ million that were oversized by a combined $\$ 22$ million. The Operations Office management expects to save about $\$ 26$ million by reassessing the need for and size of construction projects.

\section{FACTORS AFFECTING CONSTRUCTION PLANNING PROCESS}

Although the problems identified by the prior reports were at single locations, the size of the construction program and the length of the planning process could result in the recurrence of similar problems. We attempted to analyze the broader institutional impediments that were affecting appropriate construction project planning. While a myriad of concerns were raised, we noted that the extended elapsed time between identification of mission need and actual construction often encompassed significant program and/or mission changes. This was obvious given the Department's mission changes resulting from the changing geopolitical situation and its impact on the need for additional weapons production and other streamlining efforts at various Department facilities. The extended elapsed time situation necessitates that field managers evaluate and document continued mission needs and that Headquarters program managers use this information to avoid expenditures for unneeded facilities.

Past Office of Inspector General audits disclosed instances where field project managers did not effectively reevaluate and document continuing mission needs in the face of mission changes. Without this documentation, Headquarters program managers could not reassess mission needs. Further, we noted that the annual budget validation process did not provide information to facilitate Headquarters program offices' review of mission reassessments. Without documentation that there is a continued mission need, higherlevel management cannot effectively evaluate this assertion in the budget validation process.

For the 18 Defense Programs, Energy Research, and Environmental Management projects that were approved for initial construction funding in the Fiscal Year 1996 budget submission to the Congress, the elapsed time between the initial approval of mission need and the estimated date construction was to begin ranged from 2 to more than 7 years. For example, one Defense Programs construction project was approved in 1989 as meeting mission needs. Construction was not expected to start, however, until July 1997, about 8 years later. Another construction project within Environmental Management was approved as meeting mission needs in October 1991. Construction was not expected to start, however, until December 1997, more than 6 years later. Some larger projects that were funded incrementally each year took several years to complete after construction was 
started. From our limited review at the Headquarters program offices, we did not find documentation to indicate that there was a methodical process to periodically evaluate the continuing need for these projects.

The annual budget validation process did not require the field project manager to prepare documentation to show the extent to which the mission need was reassessed. For example, the process required that the original mission need be documented but did not require that an annual recertification of mission need be performed. However, the statement on the project data sheet that a mission need exists did not include supporting documentation for Headquarters to use to examine the basis for this assertion.

Documentation of the need would facilitate a review at the Headquarters level where the strategic or long-range plans for the facility could be considered in relation to available facilities at other locations. Without documentation to clearly show that a continued need will exist for the ongoing or planned construction projects, higher-level management cannot evaluate this assertion.

In the future, the Department's construction planning process will continue to be impacted by moves to downsize the weapons production complex. This point is illustrated by the Department's February 1996 "Draft Programmatic Environmental Impact Statement for Stockpile Stewardship and Management" (DOE/EIS-0236), which suggests alternatives for downsizing and consolidating facilities and operations. The alternatives for the Pantex Plant would downsize and consolidate facilities, switch weapons disassembly to the Nevada Test Site, and reduce future construction needs.

\section{IMPROVEMENTS INITIATED BY MANAGEMENT}

The Office of the Associate Deputy Secretary for Field Management was aware of prior reports and recognized that opportunities existed to improve the construction planning process. A number of actions were in process or planned to streamline the construction planning and approval process.

Under management streamlining of the construction planning process, Departmental Order 4700.1, "Project Management System" is to be replaced by a greatly condensed Departmental Order 430.1, "Life Cycle Asset Management." This new order will not affect existing contracts until site specific performance measures are established as part of the respective management and operating contracts. To assist Departmental elements in implementing this Order, the Office of Field Management issued a Good Practice Guide to Critical Decision Criteria in August 1995. This guide provides information to help the user follow a systemic process to reassess programmatic needs on projects prior to conceptual design and construction phases. This reassessment is intended to ensure that projects are adequately justified.

In addition to streamlining the construction planning and approval process, management advised that several other initiatives were being implemented. 
- The critical decision process was being revamped to facilitate a systematic, disciplined reassessment of mission justification on all projects at various levels of authority. The revamped process was in the final state of development and, when released, the guidance was expected by management to define the decision process for large projects. The guidance will require equivalent processes using a graded approach for smaller projects.

- During February 1996, the major Program Offices (Defense Programs, Energy Research, Environmental Management, and Civilian Radioactive Waste Management) consolidated their project management requirements into one common document. This document, "Joint Program Office Direction on Project Management," was intended to provide operating offices a single source for program direction on projects, including mission need justification.

- Another initiative covered the Department's compliance with the Government Performance and Results Act and the related program strategic planning governed by OMB Circular No. A-11. Under this initiative, the Department will be required to justify the mission need for each budget line item (including line-item projects) at least once every 3 years as part of the budgeting process. To address these requirements, an annual project validation process improvement team led by the Office for Field Management was being formed to ensure its implementation in the Fiscal Year 1999 budget process.

- In addition, the Office for Field Management inserted into the Corporate Budget Call a requirement that the Program Secretarial Officers certify that cost-benefit analysis have been done for each proposed new construction project. This is to ensure program and project managers that there are no existing Department facilities that can meet their mission needs more efficiently and effectively.

Further, Energy Research, Defense Programs, and Environmental Management have taken steps to provide for reassessment of projects and thus eliminate construction of unneeded or oversized projects. Management informed us that, as a result of these initiatives, the Department has canceled, descoped, or downsized a large number of projects and saved significant sums of money.

We concluded that the actions taken or initiated are positive steps. However, senior management recognized that the streamlined Order 430.1 as supplemented would not provide information to facilitate effective Headquarters program office reviews of reassessments that were made. The Order did not specifically require field project managers to document the reassessments of mission need, which were to be made under both the annual program review and the annual budget validation process. Also, although additional emphasis was to be placed on reassessment of mission needs, specific responsibility was not assigned for this action. 


\section{RECOMMENDATION}

We recommend that the Department's Associate Deputy Secretary for Field Management, in coordination with program offices and field elements, emphasize the need for effective evaluations by field project managers of the Department's current and future mission needs as part of the annual approval process for ongoing and planned construction projects.

\section{MANAGEMENT REACTION}

The Director, Office of the Associate Deputy Secretary for Field Management, responded to the initial draft report. The report was revised to incorporate this response and meetings were held with management officials to discuss the revised report. On November 4, 1996, management provided comments on the revised report and, with the exception of the Office of Energy Research, agreed with the recommendation. Management also provided detailed comments on recent Departmental actions to improve the approval process for construction projects.

Management Comments. The Director, Office of the Associate Deputy Secretary for Field Management, stated that the report's conclusions primarily relied on an analysis of six Office of Inspector General reports issued in 1994 and 1995. Because the report was based upon those previously released reports, he expressed the belief that the findings did not reflect recent actions taken by the Department to integrate project mission needs with program goals as a way of doing business.

For example, on February 9, 1996, the Office for Field Management issued its FY 1998 Project Review/Validation Guidance. This guidance delegated responsibility for ensuring that program offices validate mission needs and scope for each project. The guidance also established the requirement for documentation showing that each project ties to the site development plan and the program strategic plan.

As a result of these initiatives, the Department has canceled, descoped, or downsized a large number of projects. These actions resulted in significant savings for the Department.

Auditor Comments. We recognize that management has revised the construction planning and approval process since our Fiscal Year 1994 and 1995 reports. Using the Fiscal Year 1996 budget cycle, we analyzed the Department's construction planning and approval process including the documentation of the budget validation. This analysis, which is the basis for our recommendation, indicated that field project managers did not provide information to facilitate program office assessments of continued mission need as part of the annual approval process for ongoing and planned construction projects. We also recognize that management has a number of actions underway that they believe will enhance the approval process. However, until these management initiatives are fully 
implemented, we cannot determine their effectiveness in evaluating future mission needs and documenting these needs.

Management Comments. "The Life Cycle Asset Management (LCAM) Order 430.1 requires that mission need be addressed for all line-item projects prior to commencement of conceptual design as stated in section 6.e.(7)(a). The reassessment of the need for planned construction projects when significant events occur is not part of the Departmental Orders 4700.1 and 430.1 per se. However, current validation guidance and project management guides supporting Order 430.1, which have been issued, affirm the need to perform periodic reassessments annually and at specific critical decision points respectively." A Critical Decision Criteria Guide, released in August 1995, "contains a description of a systematic process that reassesses programmatic needs on projects prior to conceptual, design, and construction phases to ensure that projects are adequately justified."

Management further stated that "This process ensures the prioritization of programmatic needs that are consistent with programmatic mission. It is these documented needs that are subsequently converted into new projects or adjustments to ongoing projects by both DP Headquarters and the field."

Auditor Comments. Although the construction approval process requires an annual recertification of mission need for planned projects, neither the LCAM nor the Critical Decision Criteria Guide require the field project manager to prepare documentation to show the extent to which the mission need was assessed. Without knowledge of the analytical tools and substantive findings supporting the annual recertification of mission need, Headquarters program officials may not have enough data to make informed decisions on the use of Departmental construction funds. Also, the Critical Decision Criteria Guide recommends an approach; it is not a mandatory requirement.

Management Comments. Energy Research disagreed with the recommendation and stated that it put the burden of demonstrating mission need in the wrong place because the Headquarters and field program managers should demonstrate mission need. For major projects, approval of mission need is required by the Department to carry out the conceptual design. It is up to the program to convince the Department that a project is needed to meet mission need and then to make the case to find the necessary resources to execute the project. The field project manager's primary task is to see that the project is executed once the resources for the project are provided. Obviously, the program manager and the project manager are members of a team that needs to work closely together for the project to be carried out successfully.

Given this, the statement throughout the report that the field project manager is in the best position to determine and document mission need is incorrect. The report should be changed to state that the program manager, not the field manager, fulfills this role. 
Auditor Comments. The Energy Research position does not address one of the key factors impacting the construction planning process. That is, there is an extended period of time between the completion of the conceptual design and the actual construction of the project. This extended elapsed time situation necessitates that field project managers evaluate and document continued mission needs. Without this effort by the project manager, the Headquarters program manager does not have the data needed for the optimum evaluation of mission need. The auditor's position was supported by the Office for Field Management.

Management Comments. It is FM-20's position that, while all line item projects should initially be approved by the sponsoring Headquarters program office, the annual assessment of continued mission need may be done at the field level taking into consideration such factors as site comprehensive planning, particularly on infrastructuretype projects.

Auditor Comments. Management's comment is considered responsive to the recommendation.

Management Comments. Comments provided by Defense Programs and Environmental Management agreed with the recommendation. Management stated that the recommendation had been:

"addressed by Section 7.e.(3) of that Life Cycle Asset Management (LCAM) Order, DOE 0 430.1. This section states that field elements responsibilities include the need to: 'Obtain necessary approvals for projects from the sponsoring program offices including mission need and project baselines, as appropriate.' In addition, section 6.e.(5) of the LCAM order requires that the process for physical asset acquisitions be an integrated approach that includes the consideration of current mission needs and an appropriate scope."

Management provided a sample of 63 projects that were canceled, descoped or rescoped in the last 3 years. The Joint Program Office Direction on Project Management issued in February 1996 also directs field elements on specific requirements to be included in the justification of mission need documentation for all construction projects in the Department.

Further, Defense Programs stated that it is emphasizing the importance of the Joint Program Office Direction on Project Management by refining the process by which the field offices coordinate planning and critical decisions with the cognizant Headquarters program office to ensure continued mission need and program support. Defense Programs expressed the belief that responsibility for evaluating mission need as part of the annual approval process for ongoing and planned construction projects rested with the Headquarters Program Manager rather than the Field Project Manager. 
Auditor Comments. We recognize that management has initiated a number of improvements to its construction planning process since our 1994 and 1995 audit reports. However, as stated above, our analysis of the Fiscal Year 1996 annual construction planning and approval process and the budget validation process indicated that field project managers did not effectively evaluate current and future mission needs as part of the process. We believe that the field project manager is in the best position to determine and document the mission need for ongoing and planned construction projects. We recognize that the field project manager could be overruled by the Headquarters' program manager based on strategic planning information which might not be available at the local level.

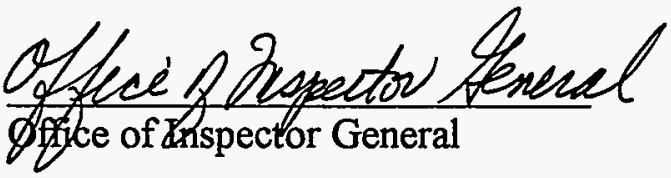




\section{SUMMARY OF INDIVIDUAL AUDIT REPORTS}

\section{Audit of the Y-12 Construction Program, CR-BC-94-02, February 14, 1994}

The Y-12 Plant is a facility that has been a major materials production and component manufacturing site in the Department's nuclear weapons complex. With the cessation of nuclear weapons production, the Department took action to revise its plans for modernizing the complex. As part of this planning process, the Department was scheduled to decide on the size and structure of the future weapons complex by December 1994. In the meantime, the sites that could be affected by the decision were to limit construction activities to what was necessary to sustain current operations and comply with environmental, safety, and health requirements.

We reported that construction planning for the $Y-12$ Plant was based on assumptions that could be incompatible with known future missions. Needs were not reassessed when the Plant's mission changed to determine if construction projects should be continued, deferred, terminated, downsized, or suspended. We recommended that the Department reassess ongoing and planned construction projects and make appropriate adjustments to ensure compatibility with current and future missions. Subsequent to the audit, management reassessed ongoing Y-12 construction and deleted $\$ 53$ million of ongoing projects.

Audit of the Uranium Solidification Facility at the Savannah River Site, DOE/IG-0349, May 25, 1994

In the late 1980s, the Department decided to construct a Uranium Solidification Facility at the Savannah River Site to process liquid uranyl nitrate into powder. The Department anticipated a continuing need to process the liquid uranyl nitrate that was generated by processing spent fuel from reactor operations. However, because of decreasing requirements for weapons material, the Department placed the reactor in cold standby in March 1993. When initially conceived, the facility's estimated cost was about $\$ 60$ million. As of November 1993, the facility's estimated total project cost had risen to $\$ 218$ million, of which $\$ 147$ million had already been spent.

We reported that the Department continued to construct a facility to process liquid uranyl nitrate although the reactor that produced this liquid was recently shut down. Construction of the facility continued because the Department's procedures did not ensure that needs for construction projects were reassessed when significant program changes occurred. Moreover, the audit identified more economical alternatives for processing existing quantities of liquid uranyl nitrate that could cost significantly less than the $\$ 71$ million needed to complete the facility. We recommended that the Manager, Savannah River Site, immediately reevaluate the project by exploring transportation and processing 
alternatives to safely and cost effectively eliminate the current inventory of liquid uranyl nitrate, while holding project costs at a minimum during the reevaluation.

The Department concurred with our recommendation and saved about $\$ 71$ million by suspending construction. In addition, the Savannah River Site Manager reported that the contractor had been directed to "pursue vigorously" the evaluation of alternatives to identify the safest and most cost-effective method of treatment of uranyl nitrate.

Audit of the Department of Energy's Environmental Molecular Sciences Laboratory. DOE/IG-0371, April 7, 1995

The Department is responsible for examining all options in acquiring major systems to ensure that funds and existing facilities and equipment are used effectively. The audit objective was to determine whether the Office of Energy Research had evaluated all practical alternatives in building and equipping the proposed Environmental Molecular Sciences Laboratory which was estimated to cost about \$230 million. Although research at the Department's laboratories had been declining, Energy Research did not consider using them as an alternative to constructing a new laboratory and procuring equipment for it. If Energy Research had fully evaluated existing alternatives within the Department's complex, it might have identified available, unused facilities appropriate for its research mission. While structural modifications might have been necessary, the available alternatives may have cost less than the estimated $\$ 230$ million for the research laboratory. Further, such action could have resulted in better utilization of existing laboratories and equipment.

The audit report showed that all practical alternatives were not evaluated as required by Departmental orders before proceeding with construction of the new laboratory. Although a contractor had conducted a site study in 1987, the study only considered sites at one location. By not evaluating alternative sites, the Department may have missed the opportunity to not only avoid spending a significant amount of the $\$ 230$ million, but also an opportunity to more effectively utilize existing national laboratories and equipment at other locations. We recommended that the Department reevaluate the project to determine if there were less costly but equally effective alternatives to new construction. Management did not concur with our recommendation and maintained that there were no practical or less cost alternatives to the construction.

Audit of Construction of Protective Force Training Facilities at the Pantex Plant, WR-B-95-06, May 5, 1995

A goal of the Department's project management system is to ensure that projects are necessary to fulfill mission needs and are cost effective. This requires the Department to justify each project and explore competitive alternatives.

Our audit found that construction of a $\$ 2.6$ million physical training facility at the Pantex Plant was not necessary to fulfill mission needs, and the Department did not 
consider all viable alternatives to constructing a $\$ 5.7$ million weapons tactics and training facility. We recommended that the Department cancel construction of the physical training facility, make needed repairs and upgrades to the existing facilities, and reduce the cost of the Security Enhancement Major System Acquisition accordingly.

Projected net savings for canceling the construction was about $\$ 1.7$ million. Management did not agree to cancel construction of the physical training facility, but agreed to perform economic analyses of alternatives before proceeding with the project.

Audit of Construction of an Environmental, Safety, and Health Analytical Laboratory at the Pantex Plant, WR-B-96-02, October 6, 1995

The Department planned to construct a laboratory at Pantex to meet mission requirements that were already being satisfied either at onsite laboratories or commercial laboratories. Construction of the laboratory was approved because the Department relied on justifications that were not updated. Furthermore, required evaluations of alternatives were either not performed or not documented. The field site had not reevaluated its need for the laboratory after the Department began to downsize the weapons complex. As a result, the Department planned to spend an additional $\$ 8.4$ million on a laboratory that was not adequately justified as necessary, that may compete with private sector laboratories, and that may not provide a sufficient appearance of independence. We recommended, and management concurred, that additional project funding be suspended until the need was clearly established and cost-benefit analyses performed and that the project be canceled if the laboratory is not justified.

\section{Audit of Construction Management at the Idaho National Engineering Laboratory,} WR-B-96-03, October 18, 1995

The Department's streamlining efforts, coupled with established policy, required the Idaho Operations Office to ensure that all construction projects were needed to support the Laboratory's mission and were cost effective. Our audit identified seven ongoing projects, totaling over $\$ 40$ million, that were either not needed or larger than needed. This situation occurred because the Idaho Operations Office either did not document or did not perform an independent verification, evaluation, and reassessment of the need for the projects. We recommended that the Idaho Operations Office review construction project plans and cancel those that did not support the laboratory's mission and reassess the need for and size of construction projects when significant events occur. Management concurred and initiated action to implement the recommendations. The Department expects to save about $\$ 26.4$ million by these actions. 
ATTACHMENT B

\section{SCOPE AND METHODOLOGY}

The audit was conducted from May through November 1995 at Headquarters, Department of Energy. We obtained and reviewed justifications for additional funding for projects under construction or for proposed construction projects submitted by field offices to three Headquarters program offices.

To accomplish the audit objective, we reviewed:

- Office of Management and Budget Circular A-109 and Departmental regulations and guidance concerning management and control of construction projects;

- the construction planning and approval process in three program offices;

- budget validation documentation for the Fiscal Year 1996 budget cycle;

- planned construction project documentation such as conceptual design reports and original project justifications;

- reports issued by the General Accounting Office; and

- interviewed key Departmental officials in the Offices of Defense Programs, Energy Research, Environmental Management, and Office of Field Management.

We also reviewed audit reports issued by the Office of Inspector General in 1994 and 1995. Recognizing that some of the problems identified at specific locations may have been addressed, we concentrated on recurring conditions to identify the actions necessary by the Department to correct the underlying causes.

Our review of the construction justification and approval process in Defense Programs, Energy Research, and Environmental Management included discussions with responsible Headquarters program and budget staff and reviews of each office's policies and procedures for approving construction projects. Our audit effort concentrated on documentation available at Headquarters and included both the program planning process and the budget validation process for construction projects.

In analyzing the construction program planning process, we compared and contrasted the practices and procedures used by the three Headquarters program offices. We analyzed the different methods and factors used to rank and prioritize the current and future construction projects at both the field offices and the Headquarters program offices. Particular attention was given to documentation that discussed consideration of alternative facilities or downsizing of planned facilities as a result of program or mission changes. 
In analyzing the budget validation process, we examined the procedures followed to obtain additional funding for ongoing and future projects. Emphasis was placed on determining what information was available to the individual performing the budget validation. In addition, we reviewed the documentation of any revalidations that were performed between the initial validation of projects and their approval by the Congress.

Although prior reports covered both large and small construction projects, our review of the planning process focused on projects with total estimated costs below $\$ 100$ million. These projects totaled about $\$ 680$ million of the Department's $\$ 1.1$ billion Fiscal Year 1996 construction budget submission. Of this amount, about $\$ 155$ million was for Defense Programs projects, $\$ 360$ million was for Environmental Management projects, and $\$ 111$ million was for Energy Research projects. The remaining $\$ 55$ million was for various construction projects within the Offices of Energy Efficiency, Nuclear Energy, and Fossil Energy.

Using the information gathered about the construction justification and approval process, we analyzed the recurring problems identified by the prior reports and the impact of actions taken to address specific causes. Because the prior reports addressed the need to reassess specific projects to ensure a continuing current or future need plus other issues, we looked at the effectiveness of the actions taken to preclude potential recurrences of similar problems. Specific attention was given to documentation of requirements of continuing mission needs as part of the annual reviews of ongoing or planned projects.

The audit was made in accordance with generally accepted Government auditing standards for performance audits and included tests of internal controls and compliance with laws and regulations to the extent necessary to satisfy the objectives of the audit. We limited the review of internal controls to the planning and approval process for construction projects and did not rely extensively on computer-generated data to develop this report. Because our review was limited, it would not necessarily have disclosed all internal control deficiencies that may have existed.

An exit conference was waived by the Office of the Associate Deputy Secretary for Field Management (FM-50). 
IG Report No._DOE/IG-0398

\section{CUSTOMER RESPONSE FORM}

The Office of Inspector General has a continuing interest in improving the usefulness of its products. We wish to make our reports as responsive as possible to our customers' requirements, and therefore ask that you consider sharing your thoughts with us. On the back of this form, you may suggest improvements to enhance the effectiveness of future reports. Please include answers to the following questions if they are applicable to you:

1. What additional background information about the selection, scheduling, scope, or procedures of the audit or inspection would have been helpful to the reader in understanding this report?

2. What additional information related to findings and recommendations could have been included in this report to assist management in implementing corrective actions?

3. What format, stylistic, or organizational changes might have made this report's overall message more clear to the reader?

4. What additional actions could the Office of Inspector General have taken on the issues discussed in this report which would have been helpful?

Please include your name and telephone number so that we may contact you should we have any questions about your comments.

Name Date

Telephone Organization

When you have completed this form, you may telefax it to the Office of Inspector General at (202) 586-0948, or you may mail it to:

Office of Inspector General (IG-1)

Department of Energy

Washington, DC 20585

Attn: Customer Relations

If.you wish to discuss this report or your. comments with a staff member of the Office of Inspector General, please contact Wilma Slaughter on (202) 586-1924. 